\title{
A Different Cause of Trauma: Injury by a Mole Gun
}

\author{
Travmanın Farklı Bir Nedeni: Köstebek Tabancasıyla Yaralanma
}

\author{
Süha TÜRKMEN,' Aydın AKTAŞ, ${ }^{2}$ Yunus KARACA,' Süleyman TüREDi,' Abdülkadir GÜNDÜZ' \\ 'Department of Emergency Medicine, Karadeniz Technical University, Faculty of Medicine, Trabzon; \\ ${ }^{2}$ Department of General Surgery, Gümüşhane State Hospital, Gümüşhane, Turkey
}

\begin{abstract}
SUMMARY
Although injuries caused by the home-made weapons such as mole guns, which are intended to fight off moles, are rare in Turkey they do still happen. They generally involve minor accidents and cause simple injuries to the hand. In this case we present a patient who involves a trauma to the left hand with fragmental fracture of the first metacarpal caused while checking whether a mole gun had fired or not. This injury is an example of an accident related to primitive, home-made weapons, used particularly in rural areas.
\end{abstract}

Key words: Hand injury; mole gun; injury.

\section{ÖZET}

Tarlaların köstebeklerden korunması amacıyla yapılan ve köstebek tabancası olarak isimlendirilen el yapımı silahlarla yaralanmalar nadir de olsa Türkiye'de meydana gelmektedir. Bunlar genellikle küçük kazalara ve elde küçük yaralanmalara neden olmaktadır. Bu yazıda, köstebek silahının patlayıp patlamadığını kontrol ederken meydana gelen sol elinde travması olan, birinci metakarpında fragmente kırığı olan bir hastayı sunduk. Bu yaralanma halen kırsal bölgelerde kullanılan ilkel ev yapımı silahlarla olan yaralanmalara bir örnektir.

Anahtar sözcükler: El yaralanması; köstebek silahı; yaralanma.

\section{Introduction}

In contrast to the high frequency of injuries caused by firearms used for defensive or aggressive purposes, those caused by primitive, home-made firearms produced for other purposes are rarely seen in the emergency department. Firearms used by individuals engaged in agriculture to combat rodents, moles in particular, produced under primitive local conditions and with poor operator safety, can lead to user injury from time to time. ${ }^{[1]}$ These injuries generally arise from accidents involving the construction, firing or carrying of the weapon, and can also have fatal consequences. ${ }^{[2]}$ There have been previous case reports of injuries inflicted with similar weapons for the purposes of suicide or as a trap for thieves. ${ }^{[2,3]}$

\section{Case Report}

A 40-year-old woman presented to the emergency department with an injury to the left hand. She stated that she had been checking to see whether the mole gun she had installed to protect her potato patch against moles and other rodents had fired when it went off by accident.

The patient exhibited crush-type cutaneous and subcutaneous tissue injuries, particularly to the proximal aspect of the first and second fingers. Distal capillary circulation difficulty was positive at examination. In addition, there were burns to various parts of her hand, thought to be related to closerange use of a firearm. While the flexor palmaris longus was preserved intact, a fragmental fracture involving the joint

Submitted (Geliş tarihi): February 10, 2011 Accepted (Kabul tarihi): March 15, 2011

Correspondence (Illetişim): Süha Türkmen, M.D. Karadeniz Technical University, Faculty of Medicine, Department of Emergency Medicine, Trabzon, Turkey

e-mail (e-posta): drsuhaturkmen@hotmail.com 

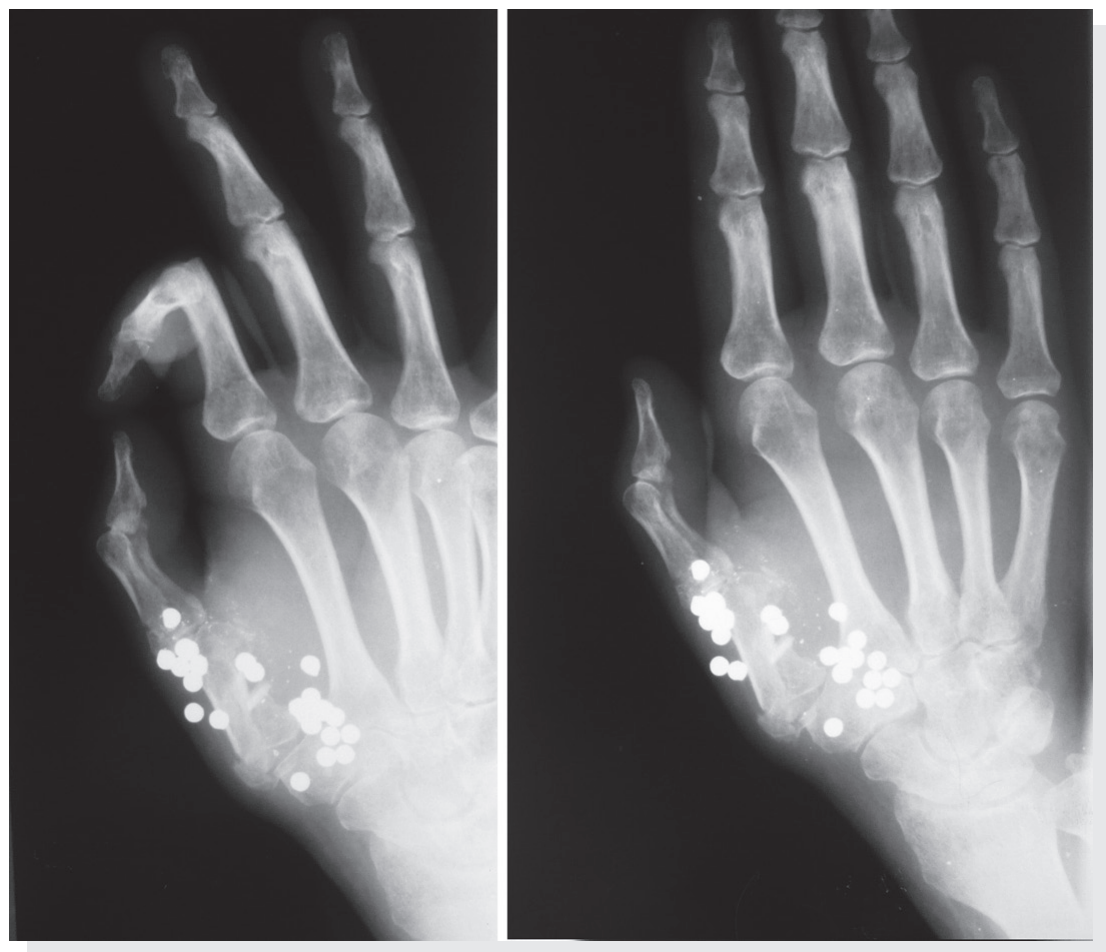

Figure 1. X-Ray of injured hand.

surface at the proximal and distal aspects of the first metacarpal bone was observed at X-ray (Figure 1). In addition, a large number of pellets were observed in the proximal aspect of the first metacarpal.

The patient's vital signs were stable. The injury site was irrigated with saline solution, the hand was placed in a splint and tetanus toxoid and antibiotherapy administered. The patient was then transferred to the Karadeniz Technical University Medical School Hospital, which operates as the university hospital hand surgery clinic for the region, for a surgery for her to be performed. Determination of the fracture in the first metacarpal was performed using a $\mathrm{K}$ fiber. The hand was placed in a splint and monitored. Capillary blood circulation of hand was observed in good condition. The pa-

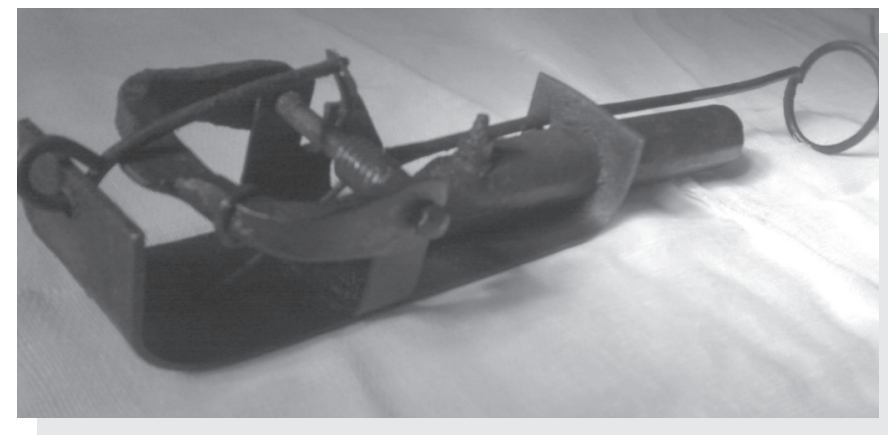

Figure 2. The mole gun mechanism is ready for to fire. tient returned for follow-up after 15 days, she could move her first finger and her hands capillary circulation was good. She was discharged with physiotherapy advice.

\section{Discussion}

Mole guns, generally placed inside rodent nests, may come in a variety of types. Figure 2 shows a mole gun ready for firing, and Figure 3 one that has been fired. The working mechanism is generally similar, though various types of gun exist.

Like other front-loading weapons, there is a metal ring at the front of the gun, which also forms part of the trigger mechanism, on which the bait is placed. When the mole puts its head through the ring to take the bait, it triggers the firing mechanism. The hammer strikes the primer and this causes

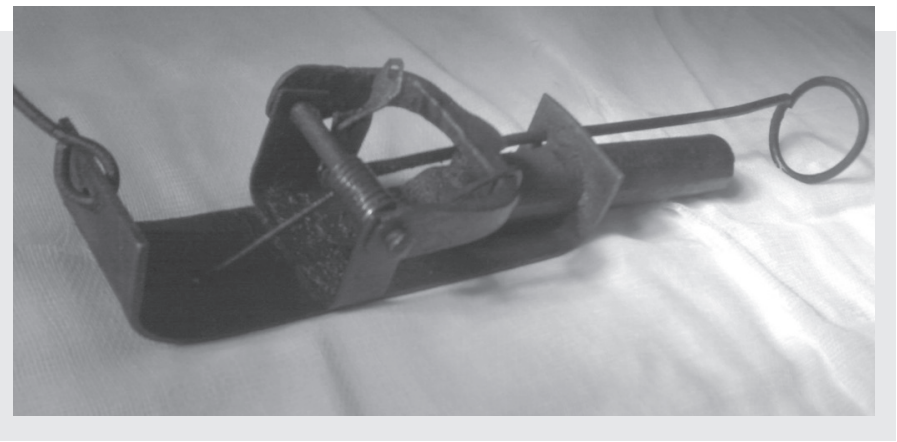

Figure 3. The mole gun has been fired. 
the powder to ignite and the pellets loaded in the barrel to be expelled. The animal in front of the barrel is thus killed or injured by the pellets. ${ }^{[4]}$ These weapons may vary in size, ranging from 20 to $40 \mathrm{~cm}$, and are generally 12-gauge in caliber. In terms of distribution of injuries caused by these weapons in Turkey, they are more widespread in the central Anatolian region (68\%) than in other regions of the country. Injuries in humans frequently occur to the hand, and there have even been rare deaths reported. ${ }^{[1]}$

\section{Conclusion}

Although it is legally forbidden to possess or manufacture home-made weapons, injuries resulting from them are still encountered today. Our aim in this case study was to emphasize that the mole gun, a primitive firearm, is still in use and may cause injuries, and sometimes even fatalities. Such injuries represent a public health issue, especially in rural areas. We think public education about modern and safe methods of combating pests will reduce the number of such injuries.

\section{Conflict of Interest}

The Author(s) declare(s) no conflict of interest related to this work.

\section{References}

1. Yılmaz R, Birincioğlu I, Çakır İ. Mole guns in Turkey in 20032005. J Forensic Sci 2007;52:114-5.

2. Demirci Ş, Günaydın IG, Doğan KH. Deaths caused from mole guns: a two cases report [in Tukish]. Proceeding of the 12th National Forensic Medicine Days; September 28-October 2 2005, Antalya, Turkey. İstanbul, Turkey: The Institude of Forensic Medicine, The Publication of the Institude of Forensic Medicine, 2006.

3. Uner B, Gürpınar SS, Çakır I. Mole gun-an unusual firearm, case note. Forensic Sci Int 2001; 118:83-85. 